\title{
Influences of Polymeric Magnetic Encapsulated Nanoparticles on the Adhesive Layer for Composite Materials Used for Class I Dental Fillings
}

\author{
CRISTIAN ZAHARIA ${ }^{1}$, COSMIN SINESCU ${ }^{1}$, ALIN-GABRIEL GABOR ${ }^{1}$, VLAD SOCOLIUC ${ }^{2}$, SERBAN TALPOS ${ }^{1}$, TAREQ HAJ AJ ${ }^{1}$, \\ PAULA SFIRLOAGA ${ }^{3}$, ROXANA OANCEA ${ }^{1 *}$, MARINELA MICLAU ${ }^{3}$, MEDA-LAVINIA NEGRUTIU ${ }^{1}$ \\ ${ }^{1}$ Victor Babes University of Medicine and Pharmacy, Faculty of Dentistry, 9 Revolutiei 1989 Blvd., 300070, Timisoara, Romania \\ ${ }^{2}$ Romanian Academy -Timisoara Branch, Center for Fundamental and Advanced Technical Research, Laboratory of Magnetic \\ Fluids, 24 Mihai Viteazu Av., 300223, Timisoara, Romania \\ ${ }^{3}$ Institute for Research and Development in Electrochemistry and Condensed Matter, 1 P. Andronescu Str. 300224, Timisoara, \\ Romania
}

\begin{abstract}
The main properties of dental adhesives should be good marginal adaptation, high retention strength and the possibility of notnegatively influencing clinical sustainability. Dental adhesives are continuously improving to increase their retention to dental structures by increasing penetration in these structures, as it was shownin the in-vitro tests requiring imaging and qualitative analysis to allow the evaluation of experimental samples as well as the development of new materials. The main objective of this study is the qualitative and quantitative analysis of the layer of modified dental adhesives with ferrous nanoparticles encapsulated in a $\mathrm{SiO}$ membrane located between the surface of the dental preparation and the surface of the photopolymerizable composite filling. For qualitative and quantitative analysis of the samples, technologies such as SEM, optical microscopy and EDX were used.
\end{abstract}

Keywords: dental adhesives, nanoparticles, SEM, EDX, optical microscopy

The development of adhesive techniques in dental medicine has increased the requirements of aesthetic dentistry as well as increasing the number of minimally invasive restorations made on dental surfaces [1].

Contemporary dentistry has been revolutionized by the appearance of dental adhesives, through it, other research directions have emerged for their improvement: the development of methacrylate-based composites, the development of hydrophilic resins and the modification of acid-engraved dental surfaces. Surfaces of dental adhesives are susceptible to biodegradation. This biodegradation includes the interaction of bacterial enzymes, endogenous enzymes and dental biofilm. Acidity and hydrophilicity of resins increase the degree of degradation of the adhesive at its interface, and modified forms of dentin and enamel can affect the adhesion of the adhesive to enamel or dentin [2].

Composite resins have surpassed amalgam and have become the most used materials for dental restorations made by direct technique. Adhesive composite restorations are threatened by secondary caries, the degradation of the adhesive layer present at the interface between the tooth and by the various defective restorationmaterials, which will then be infested by fluids, bacteria and secondary bacterial products, leading ultimately to the failure of the composite filling. Therefore the durability over time of the connections between dentin and adhesives become an issue [3].

Thus, considering the fact that the main reason for the loss of a composite restoration by bacterial colonization and the appearance of secondary caries was generated by the microfissures at the edge of the restoration, the researchers developed the first dental dhesive material that has self-healing properties with antibacterial and remineralizing action. It has increased dental adhesion qualities, but its most important property is the self-healing of fractures at the adhesive interface layer [4].
Dental adhesives have been modified over time to alleviate the deficiencies they have acquired since the first generations, with methacrylamides being added to their component, the main purpose of which is to increase the resistance to hydrolytic and enzymatic degradations occurring at the interface of the adhesive [5] .

In the formula of theadhesives components, lysine has been incorporated, which has resulted in good $\mathrm{pH}$ modulation outcomes, the effect of this modification can improve the durability of composite dental restorations [6].

Previous studies show that the thickness of the adhesive layer at the interface between the tooth and the restoration material is between $0.02 \mathrm{~mm}$ and $0.3 \mathrm{~mm}$ [7-9].

The presence of resin tags and the thickness of the hybrid layer do not greatly influence adhesion.[10, 11]The strength of adhesion may vary depending on the action time of the acid on the dental surface. At the same time, the surface of the hybrid layer changes, and the long time action of the acid on the surface of the tooth can influence the adhesion in a negative way [12].

Stress at the dentine-adhesive interface may be influenced by the type of adhesive used, with increased stress levels for self-etch adhesives compared to etch-andrinses and self-etch-primer, both adhesive systems presenting partial demineralized dentin [13].

Dental adhesives have been evaluated over the years using imaging technologies such as optical coherence tomography (OCT), scanning electron microscopy, Raman microspectroscopy and electron paramagnetic resonance spectroscopy [14-20].

\section{Experimental part}

In this study, 15 teeth were used, that had Class I Black cavities. The materials used in this study were: phosphoric acid for tooth demineralisation, Evetric Bond (Ivoclar) dental adhesive, Brilliant Flow (Coltene) photopolymerizable composite flow and multicore-shell $\mathrm{Fe}_{3} \mathrm{O}_{4}^{-}$ $\mathrm{SiO}_{2}$ magnetic nanoparticles (fig.1). 


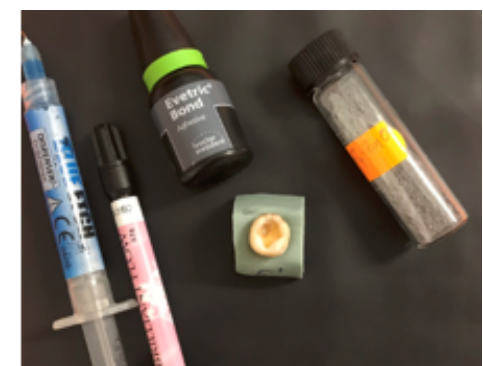

Fig.1 Materials used in this study and magnetic nanoparticles samples

After preparing the cavities on the surface of the teeth, they were restored using the adhesive technique. Demineralisation of dental surfaces was done with phosphoric acid for $15 \mathrm{~s}$ for dentin and $30 \mathrm{~s}$ for the enamel.

The acid was washed with water for $20 \mathrm{~s}$ and the surface wasdried with air. After demineralization, the dental adhesive doped with nanoparticles was applied by brushing onto the prepared surface of the cavity (fig.2).

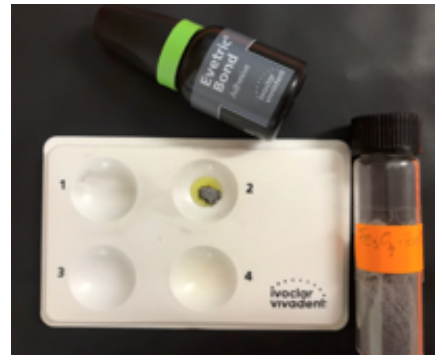

Fig.2. Nanoparticles mixing procedure with dental adhesive

For 5 teeth the adhesive was applied by brush, and for the other 10teeth after brushing the adhesive, a magnetic field was applied to the entire teeth circumference as follows: for 5 teeth the magnetic field was applied for 2 min, and for the other 5 the magnetic field was applied for 5 min (fig.3).

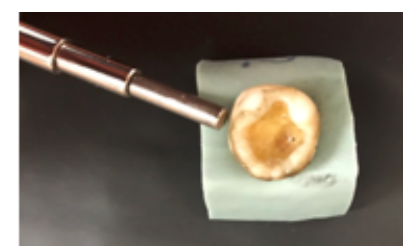

Fig.3. Adhesive application on dental surface in magnetic field for 2 and $5 \mathrm{~min}$
After applying the adhesive, it was photopolimerized with the blue light lamp for $40 \mathrm{~s}$, resulting in anaesthetic filling with slightly colored edges due to the nanomagnetic particles (fig.4).

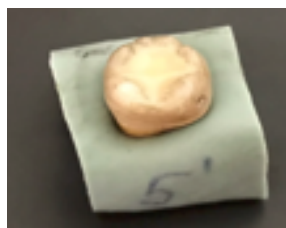

Fig.4. Aspect of filling after photopolymerization of composite material

Using a Vibrating Sample Magnetometer ADE Technologies VSM 880 we measured at room temperature the magnetization properties in the field range 0 - $1000 \mathrm{kA} /$ $m$. The magnetic particles have superparamagnetic behaviour with $71 \mathrm{emu} / \mathrm{g}$ saturation magnetization, $6.4 \mathrm{emu} / \mathrm{g}$ remnant magnetization and $4.4 \mathrm{kA} / \mathrm{m}$ coercive field.

Further, all 15 samples were sectioned and analysed with the help of FEl Inspect Sscanning electron microscope (SEM), optical microscope andEnergy Dispersive X-ray analysis(EDX). The scanning electrone microscope has the following characteristics: tungsten filament mounted in the tetrode cannery assembly with a resolution of $3.0 \mathrm{~nm}$ on standard specimen with gold particles separated on a carbon substrate. Focus domain is between 3 and $99 \mathrm{~mm}$ with a magnification from $6 \mathrm{x}$ to $>1.000 .000 \mathrm{x}$.

SEM analyzes generated images at 200x magnification in which the dental adhesive layer was observed between the two interfaces of the composite resin and the surface of the tooth structure.

Samples showing the adhesive loaded with magnetic nanoparticles that was applied to the tooth surface by conventional technique were analyzed using SEM, resulting in images at a 200x magnification. EDX quantitative analysis is showing internal components (fig.5).

The interfaces in which the dental adhesive loaded with magnetic nanoparticles was applied in the magnetic field for 2 and $5 \mathrm{~min}$ were also analyzed, generating high resolution images at the same magnification. The internal components diagram was also created (figs. 6, 7).

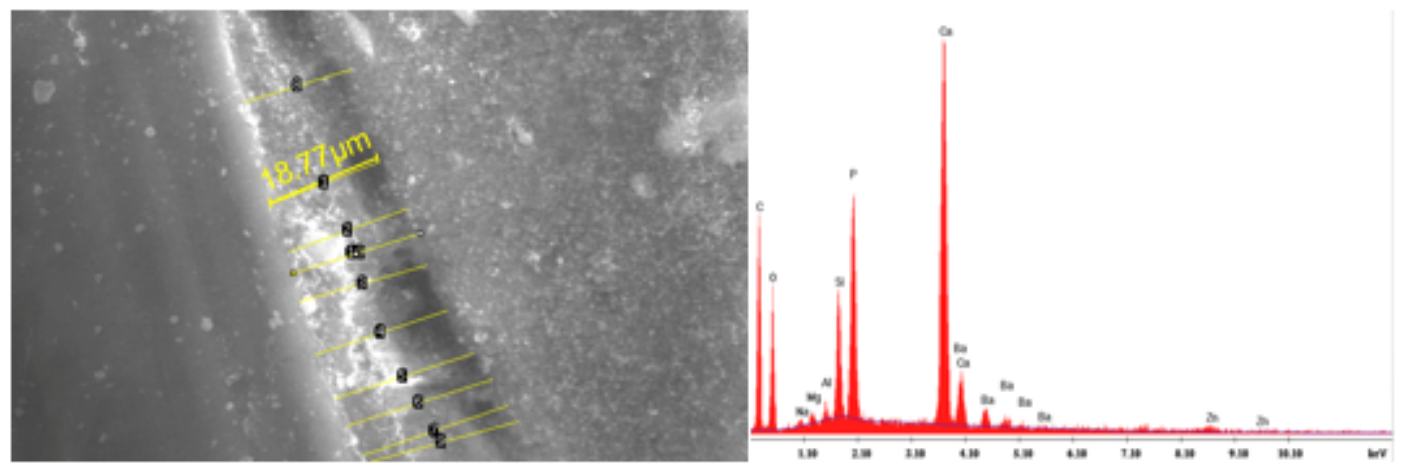

Fig.5. SEM and EDX analisys for the probes with adhesive reinforced with nanoparticles applied on teeth without magnetic field
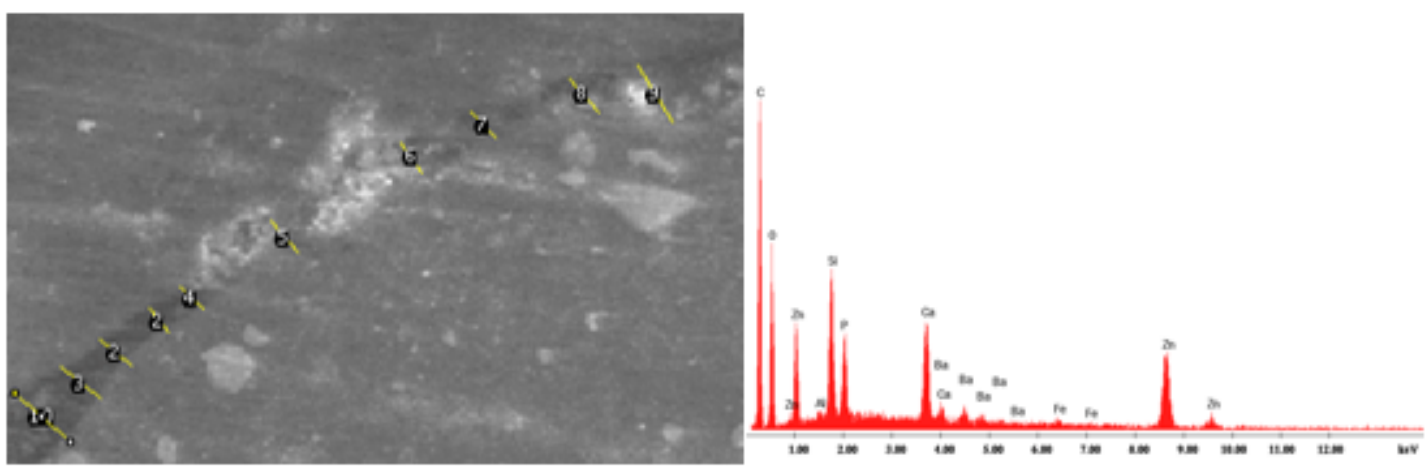

Fig.6. SEM and EDX analisys for the probes with adhesive reinforced with nanoparticles applied on teeth with magnetic field for $2 \mathrm{~min}$ 

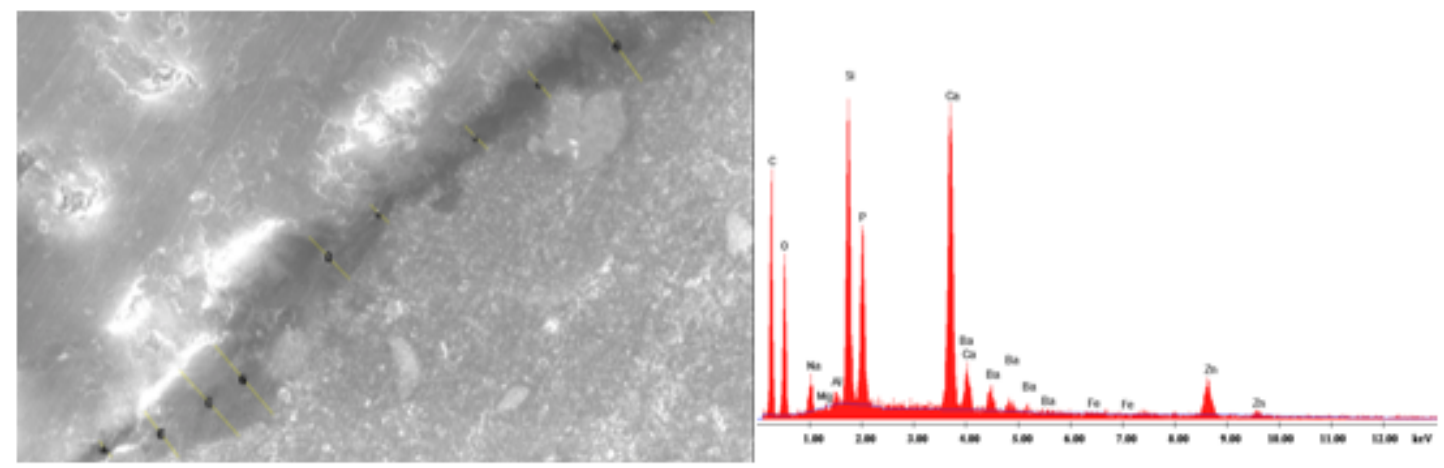

Fig.7. SEM and EDX analisys for the probes with adhesive reinforced with nanoparticles applied on teeth with magnetic field for $5 \mathrm{~min}$
All the samples were analyzed with A377 optical microscope. The microscope has a magnification range between 20X and 800X and an CMOS aquisition sensor of 2MPX. The focus is between $0 \mathrm{~mm}$ and $40 \mathrm{~mm}$ and the connection with the computer is made with USB 2.0 port. Luminosity on sample probes is adjusted manually with 10 LED lights (figs. 8-10).

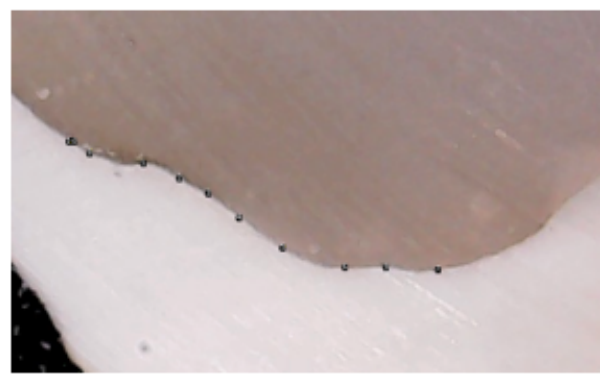

Fig.8. Optical microscope analisys for the probes with adhesive reinforced with nanoparticles applied on teeth without magnetic field

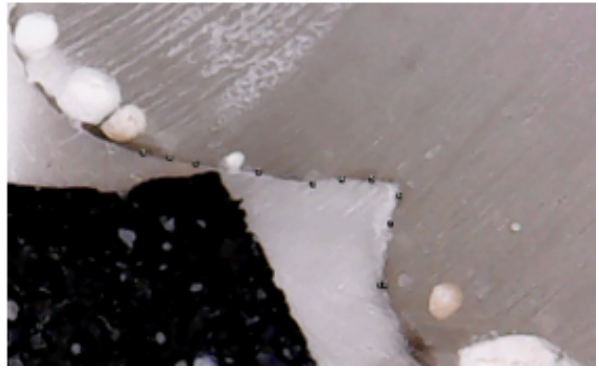

Fig.9. Optical microscopy measurements for the samples that presented dental adhesive with magnetic nanoparticles applied in magnetic field for $2 \mathrm{~min}$

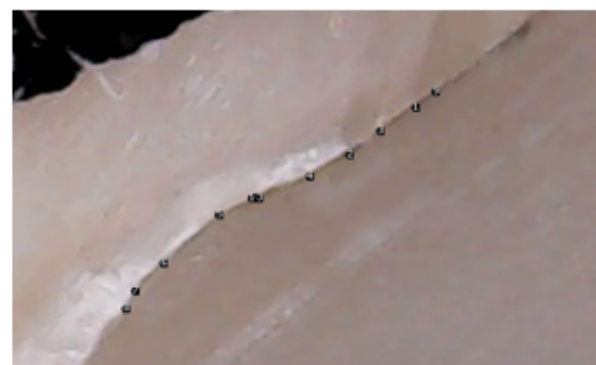

Fig.10. Optical microscopy measurements for the samples that presented dental adhesive with magnetic nanoparticles applied in magnetic field for $5 \mathrm{~min}$

\section{Results and discussions}

After recording images using SEM and optical microscopy, they were imported and analyzed using Image) software (Wayne Rasband, National Institutes of Health, USA). As a result of the measurements made on the samples where the dental adhesive was loaded with nanoparticles and applied to the surface of the teeth without magnetic field, have resulted thicknesses of the adhesive layer ranging from 10 to 25 microns (table 1 ).

For adhesives loaded with magnetic nanoparticles and applied in magnetic field for 2 min, the measurements generated adhesive layer sizes between 14 - 36 microns (table 2).

For adhesives loaded with magnetic nanoparticles and applied in the magnetic field for $5 \mathrm{~min}$, the measurements generated adhesive layer sizes between 2-12 microns.

Based on the analysis performed with optical microscopy, the thickness of adhesive layer for samples loaded with magnetic nanoparticles and applied to nonmagnetic dental surfaces were between 16-29 microns (table 4).

Table 1

SEM ANALISYS FOR DENTAL ADHESIVE LAYER THICKNESS OF THE SAMPLES REINFORCED WITH NANOPARTICLES APPLIED WITHOUT MAGNETIC FIELD

\begin{tabular}{|c|c|c|c|c|c|c|}
\hline Nr.Crt. & Area & Mean & Min & Max & Angle & $\begin{array}{c}\text { Length } \\
\text { (microns) }\end{array}$ \\
\hline 1 & 3.463 & 162.128 & 77.494 & 255.000 & 21.077 & $\mathbf{1 8 . 7 7 4}$ \\
\hline 2 & 3.763 & 179.148 & 95.330 & 253.286 & 19.895 & $\mathbf{2 0 . 3 7 7}$ \\
\hline 3 & 3.929 & 167.167 & 74.141 & 255.000 & 15.811 & $\mathbf{2 1 . 4 3 1}$ \\
\hline 4 & 4.129 & 145.630 & 73.935 & 249.820 & 18.435 & $\mathbf{2 2 . 5 0 5}$ \\
\hline 5 & 4.329 & 172.034 & 95.448 & 255.000 & 18.015 & $\mathbf{2 3 . 6 0 2}$ \\
\hline 6 & 4.529 & 142.062 & 86.200 & 224.110 & 17.632 & $\mathbf{2 4 . 7 0 1}$ \\
\hline 7 & 4.562 & 135.541 & 79.549 & 231.866 & 18.834 & $\mathbf{2 4 . 8 7 2}$ \\
\hline 8 & 3.330 & 152.661 & 97.337 & 229.965 & 16.975 & $\mathbf{1 8 . 1 2 6}$ \\
\hline 9 & 4.729 & 130.432 & 0.000 & 193.536 & 15.219 & $\mathbf{2 5 . 7 2 0}$ \\
\hline 10 & 3.963 & 177.888 & 111.652 & 255.000 & 17.210 & $\mathbf{2 1 . 5 8 7}$ \\
\hline
\end{tabular}




\begin{tabular}{|c|c|c|c|c|c|c|}
\hline Nr. Crt & Area & Mean & Min & Max & Angle & $\begin{array}{c}\text { Length } \\
\text { (microns) }\end{array}$ \\
\hline 1 & 23.443 & 92.648 & 83.187 & 113.333 & -53.130 & 14.598 \\
\hline 2 & 29.836 & 98.373 & 86.590 & 112.333 & -41.987 & 19.318 \\
\hline 3 & 38.361 & 93.172 & 83.308 & 118.333 & -39.806 & $\mathbf{2 4 . 1 7 5}$ \\
\hline 4 & 23.443 & 95.261 & 83.556 & 119.000 & -48.814 & 14.468 \\
\hline 5 & 31.967 & 116.135 & 100.551 & 139.000 & -51.340 & 20.064 \\
\hline 6 & 27.705 & 126.778 & 101.444 & 154.111 & -59.036 & 17.545 \\
\hline 7 & 27.705 & 101.435 & 88.914 & 113.444 & -45.000 & 17.893 \\
\hline 8 & 31.967 & 118.346 & 98.787 & 153.789 & -50.711 & $\mathbf{2 0 . 8 2 8}$ \\
\hline 9 & 49.016 & 129.149 & 101.000 & 156.560 & -61.189 & 32.234 \\
\hline 10 & 55.410 & 99.278 & 83.400 & 124.000 & -41.820 & 36.532 \\
\hline
\end{tabular}

Table 2

SEM ANALISYS FOR DENTAL ADHESIVE LAYER THICKNESS OF THE SAMPLES REINFORCED WITH NANOPARTICLES APPLIED WITH MAGNETIC FIELD FOR $2 \mathrm{~min}$

Table 3

SEM ANALISYS FOR DENTAL ADHESIVE LAYER THICKNESS OF THE SAMPLES REINFORCED WITH NANOPARTICLES APPLIED WITH MAGNETIC FIELD FOR $5 \mathrm{~min}$

Table 4

OPTICAL MICROSCOPY ANALYSIS FOR DENTAL SAMPLES WITH ADHESIVE REINFORCED WITH NANOPARTICLES APPLIED ON TEETH SURFACE WITHOUT MAGNETIC FIELD
Table 5

OPTICAL MICROSCOPY ANALYSIS FOR DENTAL SAMPLES WITH ADHESIVE REINFORCED WITH NANOPARTICLES APPLIED ON TEETH SURFACE WITH MAGNETIC FIELD FOR 2 min

\begin{tabular}{|l|l|l|l|l|l|l|}
\hline $\begin{array}{l}\text { Nr. } \\
\text { Crt. }\end{array}$ & Area & Mean & Min & Max & Angle & $\begin{array}{l}\text { Length } \\
(\mathrm{mm})\end{array}$ \\
\hline 1 & $2.377 \mathrm{E}-4$ & 95.037 & 69.000 & 121.000 & 45.000 & 0.022 \\
\hline 2 & $1.783 \mathrm{E}-4$ & 127.444 & 102.296 & 149.370 & 26.565 & 0.015 \\
\hline 3 & $1.783 \mathrm{E}-4$ & 165.333 & 152.333 & 177.000 & 90.000 & 0.015 \\
\hline 4 & $1.783 \mathrm{E}-4$ & 131.688 & 111.556 & 151.259 & 45.000 & 0.018 \\
\hline 5 & $1.783 \mathrm{E}-4$ & 131.130 & 129.444 & 133.778 & 45.000 & 0.013 \\
\hline 6 & $2.377 \mathrm{E}-4$ & 119.463 & 114.815 & 125.889 & 0.000 & 0.021 \\
\hline 7 & $1.783 \mathrm{E}-4$ & 133.907 & 127.667 & 139.333 & 0.000 & 0.014 \\
\hline 8 & $2.971 \mathrm{E}-4$ & 101.619 & 93.880 & 110.667 & 56.310 & 0.029 \\
\hline 9 & $2.971 \mathrm{E}-4$ & 90.217 & 68.056 & 133.778 & 63.435 & 0.033 \\
\hline 10 & $2.377 \mathrm{E}-4$ & 114.065 & 104.037 & 133.444 & 18.435 & 0.023 \\
\hline
\end{tabular}




\begin{tabular}{|l|l|l|l|l|l|l|}
\hline $\begin{array}{l}\text { Nr. } \\
\text { Crt. }\end{array}$ & Area & Mean & Min & Max & Angle & $\begin{array}{l}\text { Length } \\
(\mathrm{mm})\end{array}$ \\
\hline 1 & $1.095 \mathrm{E}-4$ & 103.861 & 99.278 & 108.444 & -45 & 0.010 \\
\hline 2 & $1.095 \mathrm{E}-4$ & 89.389 & 78.333 & 100.444 & -90 & 0.007 \\
\hline 3 & $1.095 \mathrm{E}-4$ & 115.528 & 113.667 & 117.389 & 0 & 0.007 \\
\hline 4 & $1.095 \mathrm{E}-4$ & 114.833 & 107.333 & 122.333 & -45 & 0.008 \\
\hline 5 & $5.476 \mathrm{E}-5$ & 142.111 & 142.111 & 142.111 & 0 & 0.003 \\
\hline 6 & $1.095 \mathrm{E}-4$ & 154.315 & 151.963 & 156.667 & -45 & 0.008 \\
\hline 7 & $1.095 \mathrm{E}-4$ & 143.444 & 140.778 & 146.111 & 0 & 0.005 \\
\hline 8 & $1.095 \mathrm{E}-4$ & 153.690 & 143.824 & 163.556 & 0 & 0.006 \\
\hline 9 & $1.095 \mathrm{E}-4$ & 119.583 & 118.944 & 120.222 & 0 & 0.004 \\
\hline 10 & $1.095 \mathrm{E}-4$ & 119.954 & 108.519 & 131.389 & -90 & 0.008 \\
\hline
\end{tabular}

Table 6

OPTICAL MICROSCOPY ANALYSIS FOR DENTAL SAMPLES WITH ADHESIVE REINFORCED WITH NANOPARTICLES APPLIED ON TEETH SURFACE WITH MAGNETIC FIELD FOR $5 \mathrm{~min}$
For samples using a magnetic field for $2 \mathrm{~min}$, the analyzes generated thicknesses of adhesive layer between 13-33 microns (table 5).

For samples using a magnetic field for $5 \mathrm{~min}$, the analyzes generated adhesive layer thicknesses between 3 - 10 microns (table 6).

EDX semi quantitative analysis for samples with adhesive reinforced with nanoparticles applied on teeth without magnetic field has highlighted the presence of $\mathrm{C}$ $(49.74 \%), 0(23.43 \%), \mathrm{Na}(0.46 \%), \mathrm{Mg}(0.4 \%), \mathrm{Al}(0.39$ $\%)$, Si (3.07 \%), P (6.61 \%), Ca (12.7\%), Ba (2.23\%) and Zn $(0.97 \%)$

EDX semi quantitative analysis for probes where we used magnetic field for $2 \mathrm{~min}$ has highlighted the presence of C (59.46\%), O (23.21\%), Al (0.15\%), Si (3.42\%), P (2.01 $\%), \mathrm{Ca}(2.57 \%)$, Ba (1.24\%), Fe (0.36\%) and Zn (0.97\%).

EDX semi quantitative analysis for samples where we used magnetic field for $5 \mathrm{~min}$ has highlighted the presence of C (59.46\%), O (23.21\%), Al (0.15\%), Si (3.42\%), P (2.01 $\%), \mathrm{Ca}(2.57 \%)$, Ba (1.24\%), Fe (0.36\%) and Zn (7.58\%).

Measurements made using scanning electron microscopeand optical microscopy generated results that fall within the same intervals.

\section{Conclusions}

The use of magnetic nanoparticles after incorporation into dental adhesives, can reduce the thickness of the adhesive layer by $30 \%$ by applying a magnetic field on the tooth surface for $2 \mathrm{~min}$ and by $86.5 \%$ for applying the same magnetic field for 5 min compared to the application of dental adhesives by conventional techniques.

Further studies are needed for adhesion strength evaluations.

Acknowledgement: This research was partially supported by the PhD grant of the Victor Babes University of Medicine and Pharmacy of Timi'oara - 3712/01.10.2015 (contractno.11521/01.10.2015).

\section{References}

1. ISLEINE PORTAL CALDAS, GUTEMBERG GOMES ALVES IGOR, BASTOS BARBOSA, PANTALEO SCELZA, FERNANDODE NORONHA, MIRIAM ZACCARO SCELZA, In vitro cytotoxicity of dental adhesives: A systematic review, Dental Materials, Volume 35, Issue 2, February 2019, Pages 195-205

2. ANA BEDRAN-RUSSO, ARIENE A. LEME-KRAUS, CRISTINA M.P. VIDAL, ERICA C. TEIXEIRA, An Overview of Dental Adhesive Systems and the Dynamic Tooth-Adhesive Interface, Dental Clinics of North America, Volume 61, Issue 4, October 2017, Pages 713-731
3. LINYONG SONG, QIANG YE, XUEPING GE, ANIL MISRA, CANDAN TAMERLER, PAULETTE SPENCER, New silyl-functionalized BisGMA provides autonomous strengthening without leaching for dental adhesives, Acta Biomaterialia, Volume 83, 1 January 2019, Pages 130 139

4. SHICHAO YUE, JUNLING WU, QIANG ZHANG, KE ZHANG, MICHAEL D. WEIR, SATOSHI IMAZATO, YUXING BAI, HOCKIN H.K. XU, Novel dental adhesive resin with crack self-healing, antimicrobial and remineralization properties, Journal of Dentistry, Volume 75, August 2018, Pages 48-57

5. ANA P. FUGOLIN, ADAM DOBSON, WILBES MBIYA, OSCAR NAVARRO, JACK L. FERRACANE, CARMEM S. PFEIFER, Use of (meth)acrylamides as alternative monomers in dental adhesive systems, Dental Materials, Volume 35, Issues 5, May 2019, Pages 686-696

6. LINYONG SONG, XUEPING GE, QIANG YE, KYLE BOONE, SHENGXUE XIE, ANIL MISRA, CANDAN TAMERLER, PAULETTE SPENCER, Modulating $\mathrm{pH}$ through lysine integrated dental adhesives, Dental Materials, Volume 34, Issue 11, November 2018, Pages 1652-1660 7. K.K. CHOI, J. R. CONDON, J .L. FERRACANE, The Effects of Adhesive Thickness on Polymerization Contraction Stress of Composite, J ournal of Dental Research, Volume: 79 issue: 3, page(s): 812-817, March 1, 2000

8. BART VAN MEERBEEK, KIRSTEN VAN LANDUYT, JAN DE MUNCK, MASANORI HASHIMOTO, MARLEEN PEUMANS, PAUL LAMBRECHTS, YASUHIRO YOSHIDA, SATOSHI INOUE, KAZUOMI SUZUKI, TechniqueSensitivity of Contemporary Adhesives, Dental Materials Journal 24 (1) : 1 - 13, 2005

9. ES GROSSMAN, S SETZER, Bonding agents: adhesive layer thickness and retention to cavity surfaces with time, SADJ , Original Paper, June 2001, Vol. 56, No.6

10. YOSHIYAMA M, CARVALHO R, SANO H, HORNER J, BREWER PD, PASHLEY DH. Interfacial morphology and strength of bonds made to superficial versus deep dentin. Am J Dent 1995; 8: 297-302

11. INOUE S, VARGAS MA, ABE Y, YOSHIDA Y, LAMBRECHTS $P$, VANHERLE G, SANO H, VAN MEERBEEK B. Microtensile bond strength of eleven contemporary adhesives to dentin. J Adhes Dent 2001; 3: 237-245.

12. M HASHIMOTO, H OHNO, K ENDO, M KAGA, H SANO, H OGUCHI, The effect of hybrid layer thickness on bond strength: demineralized dentin zone of the hybrid layer, Dental Materials, Volume 16, Issue 6 , November 2000, Pages 406-411

13. RODOLFO BRUNIERA ANCHIETA, LUCAS SILVEIRA MACHADO, RENATO HERMAN SUNDFELD, ANDRÉ FIGUEIREDO REIS, MARCELO GIANNINI, MARCO ANTONIO LUERSEN, MALVIN JANAL, EDUARDO PASSOS ROCHA, PAULO G.COELHO, Effect of partially demineralized dentin beneath the hybrid layer on dentin-adhesive interface micromecanics, Journal of Biomechanics, Volume 48, Issue 4, 26 february 2015, Pages 701-707 
14. ALEXANDRA R. COCCO, GIANA S. LIMA, FERNANDA B. LEAL, ELISEU A. MUNCHOW, FABRÍCIO A. OGLIARI, EVANDRO PIVA, Addition of nanoparticles for development of radiopaque dental adhesives, International J ournal of Adhesion and Adhesives, Volume 80, January 2018, Pages 122-127

15. JIRUN SUN, ELIJAH J. PETERSEN, STEPHANIE S.WATSON, CHRISTOPHER M. SIMS, ALEXANDER KASSMAN, STANISLAV FRUKHTBEYN, DRAGO SKRTIC, MERYEM T. OK, DEBBIE S. JACOBS, VYTAS REIPA, QIANG YE, BRYANT C. NELSON, Byophisical characterization of functionalized titania nanoparticles and their application in dental adhesives, Acta Biomaterialia, Volume 53, 15 april 2017, Pages 585-597

16. JUN ZHOU, WURIHANA YO SHIBATA, REINA TANAKA, ZHONGPU ZHANG, KEKE ZHENG, QING LI, SACHIKO IKEDA, PING GAO, TAKASH MIYAZAKI, Quantitative/qualitative analysis of adhesive-dentin interface in the presence of 10-methacryloyÿboxydecyl dihydrogen phosphate, Journal of the Mechanical Behavior of Biomedical Materials, Volume 92, April 2019, Pages 71-78
17. N. A. AL-EESA, N. KARPUKHINA, R. G. HILL, A. JOHAL, F. S. L. WONG, Bioactive glass composite for orthodontic adhesives Formation and characterisation of apatites using MAS-NMR and SEM, Dental Materials, Volume 35, Issue 4, April 2019, Pages 597-605

18. SINESCU, C., MARSAVINA, L., NEGRUTIU, M.L., RUSU, L.C., ARDELEAN, L., ROMINU, M., ANTONIAC, I., TOPALA, F. I., PODOLEANU, A., New metallic nanoparticles modified adhesive used for time domain optical coherence tomography evaluation of class II direct composite restoration, Rev. Chim. (Bucharest), 63, no. 4, 2012, p. 380-383

19. SZUHANEK CAMELIA, FAUR NICOLAE, CERNESCU ANGHEL Biomechanical 3D Analysis of Stress Induced by Orthodontic Implants, Key Engineering Materials, Vol. 399, pp. 199-204, 2009.

20. SZUHANEK, C., JIANU, R., CIRCIUMARU, L., NEGRUTIU, M., SINESCU, C., CLONDA, C., SCHILLER, E., POPA, A., GRIGORE, A., Microstructural Changes in Orthodontic Arch-wires after Alternative Bending Techniques Rev. Chim.(Bucharest), 67, no.11 , 2016

Manuscript received: 24.04 .2019 